\title{
The Empirical Research on the Correlation Between the Internal Control and Earning Management in Private Listed Companies
}

\author{
Sheng-Nan Yan $^{1}$ \\ ${ }^{1}$ School of Economics and Management, Beijing Jiaotong University, Beijing 100044, China
}

\begin{abstract}
Under the background of industrial innovation, this paper takes the data of private listed companies from 2011 to 2016 as the sample for empirical analysis, and finds that internal control is an important factor in earnings management. There is a significant negative correlation between internal control and accrued earnings management and real earnings management. That is to say, having a good and rigorous internal control system can effectively reduce earnings management. Moreover, compared with earnings management of accounting selective activities, internal control has more restrictive effect on earnings management of real activities.
\end{abstract}

\section{Introduction}

With the change of industrial economic structure and the rapid development of non-state-owned economy in China, private enterprises have become an important team in the development of our national economy. The total economic output created by private enterprises accounts for more than $60 \%$ of the total national economic output. In his recent important speech at the seminar on private enterprises, General Secretary $\mathrm{Xi}$ Jinping took promoting the healthy development of private enterprises as an important duty and task. By the end of 2017, the number of private enterprises in China had exceeded 27 million. However, with the intensification of competition, in order to prevent the acquisition and merger of enterprises, the position of senior managers is replaced, which gives rise to the motivation of earnings management. In addition, private enterprises lack credit, have greater risks and are facing financing difficulties. Managers manipulate earnings in order to obtain financial channels. From Wanfushengke and Guangzhou Xinda financial information fraud to the recent false profits of Yabat and Erkang Pharmaceuticals, private enterprises have become the main force of financial fraud cases in the process of rapid development and growth. In order to protect the interests of all sectors of society, many scholars began to explore the influencing factors of earnings management.

In recent years, scholars have begun to pay attention to the relationship between earnings management and internal control, but scholars have different conclusions on the correlation between them. Some scholars believe that private enterprises with the characteristics of small size, growing life cycle and imperfect financial management system often have large internal control loopholes (Doyle, 2005) ${ }^{[1]}$. On this basis, the larger the loopholes of internal control, the lower the quality of accruals (Chan et al. 2008) ${ }^{[2]}$. Improving the quality of internal control through implementing improvement measures is an effective way to reduce accounting choice earnings management (Asbaugh Skaife et al. 2008) ${ }^{[3]}$. And when internal control defects occur at the corporate level, the negative correlation between internal control quality and earnings management is more significant (Doyle, 2007) ${ }^{[4]}$. However, some scholars hold the opposite viewpoint. They believe that after perfecting the internal control system of listed companies, there is no obvious decline in earnings management ( $\mathrm{Yu}$ Zhongbo and Tian Gaoliang, 2009) $)^{[5]}$. This conclusion may be due to the distortion of the internal control self-evaluation report of listed companies under the background of the internal control system of China at that time (Zhang Guoqing, 2008) ${ }^{[6]}$.

This paper explores the relationship between internal control and earnings management of private enterprises, which is of positive significance. On the one hand, it can provide theoretical basis for seeking ways to suppress earnings management, on the other hand, it can promote the healthy and sustainable development of private listed companies and capital market.

\section{Research theory and hypothesis}

Earnings management can be divided into accrued earnings management and real activity earnings management. Accrued earnings management is the most traditional and common way of earnings management used by management. Including the use of accounting policies, estimates of changes, such as the selection of inventory valuation and depreciation methods of fixed assets, or the use of accruals management, such as enterprises can increase or reduce profits by changing the time to recognize revenue and expenses. The main objective of internal control is to restrict the behavior of

* Corresponding author: 3131562837@qq.com 
management and ensure the reliability and accuracy of financial statement information. Accordingly, this paper proposes hypothesis 1:

Hypothesis 1: There is a significant negative correlation between the quality of internal control and accrued earnings management of private listed companies, that is to say, improving the level of internal control can effectively reduce the degree of accrued earnings management.

Real activity earnings management refers to managers manipulating earnings by non-accounting methods, such as fictitious transactions, related party transactions and changing transaction attributes. True earnings management can be measured in three aspects: sales control, production cost control and discretionary cost control (Roychowdury, 2006)[7]. Sales manipulation is to attract customers and increase sales volume by means of lower sales prices and loose credit conditions, so as to increase profits. Discretionary cost manipulation is a way for managers to reduce discretionary costs, such as R\&D expenditure, advertising expenditure and other expenditures that can not bring benefits to the current period to expand the surplus. Production cost manipulation is a method for enterprises to carry out large-scale production and share fixed costs by increasing production quantity, so as to reduce operating costs and increase profits. In practice, accrued earnings management has a great risk, while real earnings management is a tool preferred by managers because of its strong concealment, small risk and high sensitivity. Accordingly, this paper proposes hypothesis 2:

Hypothesis 2: There is a significant negative correlation between the quality of internal control and earnings management of real activities in private listed companies. That is to say, improving the level of internal control can effectively reduce the level of earnings management of real activities.

\section{Variables and research design}

\subsection{Model of earnings management}

Accounting Choice Earnings Management. This paper uses the modified extended Jones model of Lujianqiao (1999) to measure accrued earnings management ${ }^{[8]}$. Compared with the revised Jones model, it considers the main influencing factors of non-manipulative accrued profits: intangible assets and other long-term assets. That is, Eq.1:

$$
\frac{N D A_{i, t}}{A_{i, t-1}}=\alpha_{1} \frac{1}{A_{i, t-1}}+\alpha_{2} \frac{\Delta S A L E S_{i, t}}{A_{i, t-1}}+\alpha_{3} \frac{P P E_{i, t}}{A_{i, t-1}}+\alpha_{4} \frac{I A_{i, t}}{A_{i, t-1}}+\xi
$$

Among them, $\mathrm{NDA}_{i, t}$ is the total accrued profit of $i$ company in the $t$ year, the amount of which is equal to the difference between operating profit and cash flow of operating activities; SALES $\mathrm{S}_{\mathrm{i}} \mathrm{t}$ means the change in operating income of $i$ company in the $t$ year (equal to the difference between the actual operating income of the company in the $t$ year and the actual operating income in the $\mathrm{t}-1$ year); $\mathrm{PPE}_{\mathrm{i}, \mathrm{t}}$ is the original cost of fixed assets at the end of the $t$ year; $I_{i, t}$ is intangible assets in the $t$ year and other long-term assets. The sum of assets; $A_{i, t-1}$ is the total assets of $i$ company at the end of $t-1$ year. According to the results of model (1), the expected accrued profit can be obtained. Accountants choose earnings management $\left|D_{D N D} A_{i, t}\right|$ as the absolute value of the difference between their actual and expected values.

Earnings Management of Real Activities. This paper refers to Roychowdhury's (2006) viewpoint and constructs a real activity earnings management model by constructing the linear relationship among sales, production costs and discretionary costs.

Operating Cash Flow Model. Using a linear function relationship, it is composed of cash flow of business activities, current business income and current business income changes. To measure the degree of cash flow manipulation of business activities by means of price discounts and credit policies in the form of relative quantities, an expected estimation model (Roychowdhury, 2006) is obtained. See Eq.2:

$$
\frac{C F O_{i, t}}{A_{i, t-1}}=\alpha_{1} \frac{1}{A_{i, t-1}}+\alpha_{2} \frac{S A L E S_{i, t}}{A_{i, t-1}}+\alpha_{3} \frac{\Delta S A L E S_{i, t}}{A_{i, t-1}}+\xi
$$

As mentioned above, $\mathrm{CFO}_{\mathrm{i}, \mathrm{t}}$ is the net cash flow of operating activities in the year $t$; SALES $_{i, t}$ represents the operating income in the year t. According to the model, the expected operating cash flow is different from the actual value of the company. The difference is $\mathrm{DCFO}_{\mathrm{i}, \mathrm{t}}$.

Production Cost Model. There is a functional relationship between production cost and current business income, current business income change and last year's business income change, and the quantity is equal to the sum of current business cost and inventory change. The Eq.3:

$$
\frac{\operatorname{PROD}_{i, t}}{A_{i, t-1}}=\alpha_{1} \frac{1}{A_{i, t}}+\alpha_{2} \frac{S A L E S_{i, t}}{A_{i, t-1}}+\alpha_{3} \frac{\Delta S A L E S_{i, t}}{A_{i, t-1}}+\alpha_{4} \frac{\Delta S A L E S_{i, t-1}}{A_{i, t-1}}+\xi
$$

Among them, PROD $_{i, t}$ is the production cost of company $i$ in the $t$ year; SALES $_{i, t-1}$ represents the change of business income in the $\mathrm{t}-1$ year. Operational production costs DPROD $_{\mathrm{i}, \mathrm{t}}$. It is equal to the difference between the actual production cost and the expected value.

Discretionary Cost Model. There is a functional relationship between the discretionary cost and the last year's annual sales revenue. The discretionary expenses include sales and management expenses. The following is its estimation model, such as Eq.4:

$$
\frac{D I S E X P_{i, t}}{A_{i, t-1}}=\alpha_{1} \frac{1}{A_{i, t-1}}+\alpha_{2} \frac{S A L E S_{i, t-1}}{A_{i, t-1}}+\xi
$$

Among them, DISEXP $\mathrm{i}_{\mathrm{i}, \mathrm{t}}$ is the discretionary cost of company $\mathrm{i}$ in the $\mathrm{t}$ year. Operational discretionary cost DDISEXP $_{i, t}$ is derived from the difference between actual and expected discretionary cost. 
Total Earnings Management Model of Real Activities. The real earnings management of listed companies may be motivated by financing, tax avoidance, avoiding political costs and avoiding debt contract constraints. The total earnings management of real activities is to subtract the value of DCFO from DPROD and DDISEXP. For example, model Eq.5:

$$
\operatorname{DREM}_{i, t}=\mathrm{DPROD}_{i, t}-\mathrm{DCFO}_{i, t}-\mathrm{DDISEXP_{i,t }}
$$

\subsection{Measurement of internal control}

In this paper, we use the internal control index IC provided by Dibo listed companies to do empirical research with quantitative data instead of internal control.

\subsection{Model of the relation between internal control and earnings management}

In order to verify hypothesis 1 and 2 , this paper builds a model Eq.6:

$$
D E M_{i, t}=\beta_{0}+\beta_{1} I C_{i, t}+\beta_{2} X_{i, t}+\varepsilon_{i, t}
$$

For example, $\mathrm{DEM}_{\mathrm{i}, \mathrm{t}}$ represents earnings management, including five variables: $\left|\mathrm{DNDA}_{\mathrm{i}, \mathrm{t}}\right|$, DDISEXP $_{i, t}$, DREM $_{i, t}$, DPROD $_{i, t}$, DCFO $_{i, t}, I_{i, t}$ is the revised internal control index; $\mathrm{X}_{\mathrm{i}, \mathrm{t}}$ represents some control variables such as ownership concentration, return on net assets, company size, board size, business income growth rate and management compensation. For details, see Table 1:

Table 1. Variable Definition Table

\begin{tabular}{|c|c|c|c|}
\hline & SIZE & $\begin{array}{l}\text { Scale of } \\
\text { company }\end{array}$ & $\begin{array}{l}\text { The natural } \\
\text { logarithm of the } \\
\text { total assets of a } \\
\text { listed company at } \\
\text { the end of the year }\end{array}$ \\
\hline \multirow[t]{4}{*}{$\begin{array}{l}\text { Control } \\
\text { variable }\end{array}$} & ROE & $\begin{array}{l}\text { Return on } \\
\text { equity }\end{array}$ & $\begin{array}{l}\text { Average balance of } \\
\text { net } \\
\text { profit/stockholder's } \\
\text { equity }\end{array}$ \\
\hline & BOD & Board size & $\begin{array}{l}\text { The number of } \\
\text { directors disclosed } \\
\text { in the annual peport }\end{array}$ \\
\hline & MOIG & $\begin{array}{l}\text { Increase rate of } \\
\text { business } \\
\text { revenue }\end{array}$ & $\begin{array}{l}\text { (Operating income } \\
\text { amount of the } \\
\text { current period of } \\
\text { the current year - } \\
\text { operating income } \\
\text { amount of the same } \\
\text { period of the } \\
\text { previous } \\
\text { year)/(operating } \\
\text { income amount of } \\
\text { the same period of } \\
\text { the previous year) } \\
\end{array}$ \\
\hline & SAL & $\begin{array}{l}\text { Executive } \\
\text { compensation }\end{array}$ & $\begin{array}{l}\text { Total compensation } \\
\text { of the top three } \\
\text { executives } * 10 / \text { total } \\
\text { assets }\end{array}$ \\
\hline
\end{tabular}

\begin{tabular}{|l|l|l|l|}
\hline $\begin{array}{l}\text { Variable } \\
\text { Type }\end{array}$ & $\begin{array}{l}\text { Variable } \\
\text { Code }\end{array}$ & Variable Name & Variable Definition \\
\hline DNDA & $\begin{array}{l}\text { Accrued } \\
\text { earnings } \\
\text { management }\end{array}$ & $\begin{array}{l}\text { Accrued earnings } \\
\text { management degree }\end{array}$ \\
\hline $\begin{array}{l}\text { Dependent } \\
\text { variable }\end{array}$ & DCFO & $\begin{array}{l}\text { Opeal earnings } \\
\text { management } \\
\text { cash flow }\end{array}$ & $\begin{array}{l}\text { True earnings } \\
\text { management }\end{array}$ \\
\hline DPROD & $\begin{array}{l}\text { Operational } \\
\text { control of sales }\end{array}$ & $\begin{array}{l}\text { Degree of control } \\
\text { over production } \\
\text { production } \\
\text { costs }\end{array}$ \\
\hline DREM & Discretionary & $\begin{array}{l}\text { Degree of } \\
\text { discretionary cost } \\
\text { control }\end{array}$ \\
\hline $\begin{array}{l}\text { Independent IC } \\
\text { variable }\end{array}$ & CR & $\begin{array}{l}\text { Revised internal } \\
\text { control index }\end{array}$ & $\begin{array}{l}\text { Dibble internal } \\
\text { control index } \\
\text { divided by 1000 }\end{array}$ \\
\hline concentration & $\begin{array}{l}\text { Share proportion of } \\
\text { the largest } \\
\text { shareholder }\end{array}$ \\
\hline
\end{tabular}

\section{Empirical analysis}

\subsection{Sample selection}

This paper takes the data of all private listed companies in Shanghai and Shenzhen Stock Exchanges from 2011 to 2016 as the research sample. The sample data used are from Cathay Taian database and Reiss database. The internal control index used is from the internal control index report issued by Dibo listed companies. Sample data are processed as follows:

Exclude companies listed after 2011

Exclude companies that were specially treated between 2011 and 2016, such as * ST Company and ST Company.

The selected variables are tailed at $1 \%$ and $99 \%$ to avoid the influence of extreme values on the results.

After processing the above data, 3838 samples were obtained.

\subsection{Relevance analysis}

In this paper, Pearson coefficient is used to analyze the correlation between variables, and the degree of correlation between variables is measured. The results of correlation analysis are as follows: Table 2. 
Table 2. Correlation coefficient table

\begin{tabular}{|c|c|c|c|c|c|c|c|c|c|c|c|}
\hline & DNDA & DCFO & DPROD & DDISEXP & DREM & IC & CR & SIZE & ROE & BOD & MOIG \\
\hline & 1 & & & & & & & & & & \\
\hline DNDA & & & & & & & & & & & \\
\hline DCFO & $-0.0426 * * *$ & 1 & & & & & & & & & \\
\hline & 0.0083 & & & & & & & & & & \\
\hline DPROD & $-0.1019 * * *$ & $-0.3375 * * *$ & 1 & & & & & & & & \\
\hline & 0.0000 & 0.0000 & & & & & & & & & \\
\hline DDISEXP & $0.1678^{* * *}$ & $0.2605^{* * *}$ & $-0.6833^{* * *}$ & 1 & & & & & & & \\
\hline & 0.0000 & 0.0000 & 0.0000 & & & & & & & & \\
\hline DREM & $-0.0406 * *$ & $-0.6355 * * *$ & $0.8913 * * *$ & $-0.7652 * * *$ & 1 & & & & & & \\
\hline & 0.0118 & 0.0000 & 0.0000 & 0.0000 & & & & & & & \\
\hline IC & $-0.1176^{* * *}$ & $0.1018^{* * *}$ & $-0.2081 * * *$ & $0.1384 * * *$ & $-0.2007 * * *$ & 1 & & & & & \\
\hline & 0.0000 & 0.0000 & 0.0000 & 0.0000 & 0.0000 & & & & & & \\
\hline CR & $0.0384 * *$ & $0.0875^{* * *}$ & $-0.1200^{* * *}$ & $0.0719 * * *$ & $-0.1120^{* * *}$ & $0.1713^{* * *}$ & 1 & & & & \\
\hline & 0.0174 & 0.0000 & 0.0000 & 0.0000 & 0.0000 & 0.0000 & & & & & \\
\hline SIZE & -0.0102 & $0.0273 *$ & $-0.1193 * * *$ & $0.0675^{* * *}$ & $-0.0962 * * *$ & $0.2627 * * *$ & $0.2403 * * *$ & 1 & & & \\
\hline & 0.529 & 0.0908 & 0.0000 & 0.0000 & 0.0000 & 0.0000 & 0.0000 & & & & \\
\hline ROE & $0.0666^{* * *}$ & $0.2056^{* * *}$ & $-0.4091 * * *$ & $0.2422 * * *$ & $-0.3709^{* * *}$ & $0.3514^{* * *}$ & $0.2013 * * *$ & $0.2035^{* * *}$ & 1 & & \\
\hline & 0.0000 & 0.0000 & 0.0000 & 0.0000 & 0.0000 & 0.0000 & 0.0000 & 0.0000 & & & \\
\hline BOD & -0.0072 & 0.0186 & $-0.0735^{* * *}$ & $0.0506^{* * *}$ & $-0.0661 * * *$ & $0.0440 * * *$ & -0.0185 & $0.1861^{* * *}$ & $0.0782 * * *$ & 1 & \\
\hline & 0.6579 & 0.2499 & 0.0000 & 0.0017 & 0.0000 & 0.0064 & 0.2532 & 0.0000 & 0.0000 & & \\
\hline MOIG & $0.4843^{* * *}$ & $0.0529 * * *$ & $-0.1802 * * *$ & $0.3120^{* * *}$ & $-0.1585^{* * *}$ & -0.0117 & $0.0433 * * *$ & $0.0368^{* *}$ & $0.1662 * * *$ & -0.0092 & 1 \\
\hline & 0.0000 & 0.0011 & 0.0000 & 0.0000 & 0.0000 & 0.4711 & 0.0074 & 0.023 & 0.0000 & 0.5676 & \\
\hline SAL & $0.0498 * * *$ & $-0.0273 *$ & $0.0708^{* * *}$ & -0.02 & $0.0571 * * *$ & $-0.2238^{* * *}$ & $-0.1846 * * *$ & $-0.6077 * * *$ & $*-0.0647 * * *$ & $-0.0836 * * *$ & $-0.0307^{*}$ \\
\hline & 0.002 & 0.091 & 0.0000 & 0.2145 & 0.0004 & 0.0000 & 0.0000 & 0.0000 & 0.0001 & 0.0000 & 0.0574 \\
\hline
\end{tabular}

significant at the levels of $1 \%, 5 \%$ and $10 \%$ respectively. 
From Table 2, we can see that DNDA is negatively correlated with DREM and DPROD at $5 \%$ and $1 \%$, DREM is positively correlated with DPROD at $1 \%$ and negatively correlated with DCFO and DDISEXP at $1 \%$ respectively. DCFO is negatively correlated with DPROD and DDISEXP at $1 \%$ level, which indicates that there are obvious differences among the explanatory variables selected to measure earnings management. The correlation is consistent with the principle of model construction. That is to say, earnings management indicators are better chosen.

Secondly, IC is negatively correlated with DNDA at $1 \%$ significance level, negatively correlated with DREM and DPROD at $1 \%$ significance level, and positively correlated with DCFO and DDISEXP at $1 \%$ level. It can be inferred that in private listed companies, improving the quality of internal control can significantly reduce the degree of accrued earnings management and real activity earnings management. But the real conclusion needs to be verified by further multiple linear regression analysis.

\subsection{Multivariate Regression Analysis}

In order to verify hypothesis 1 and 2, this paper takes five variables DNDA, DCFO, DPROD, DDISEXP and DREM as dependent variables, regards internal control index as independent variable, and then establishes a multivariate regression mathematical model for statistical analysis. The regression results are shown in Table 3.

Table 3. Return Result of Earnings Management and Internal Control

\begin{tabular}{|c|c|c|c|c|c|c|c|c|c|c|}
\hline & \multicolumn{2}{|l|}{ DNDA } & \multicolumn{2}{|l|}{ DCFO } & \multicolumn{2}{|l|}{ DPROD } & \multicolumn{2}{|l|}{ DDISEXP } & \multicolumn{2}{|l|}{ DREM } \\
\hline & $\begin{array}{l}\text { Estimation } \\
\text { coefficient }\end{array}$ & t value & $\begin{array}{l}\text { Estimation } \\
\text { coefficient }\end{array}$ & t value & $\begin{array}{l}\text { Estimation } \\
\text { coefficient }\end{array}$ & t value & $\begin{array}{l}\text { Estimation } \\
\text { coefficient }\end{array}$ & t value & $\begin{array}{l}\text { Estimation } \\
\text { coefficient }\end{array}$ & t value \\
\hline $\begin{array}{l}\text { Intercept } \\
\text { term }\end{array}$ & 0.0604688 & 1.55 & 0.0503501 & 1.16 & 0.1689925 & $2.63 * * *$ & -0.1223476 & $-3.08 * * *$ & 0.2253256 & $1.93 *$ \\
\hline IC & -0.079999 & $-7.44 * * *$ & 0.0134412 & 1.13 & -0.0802305 & $-4.52 * * *$ & 0.0526332 & $4.8 * * *$ & -0.1493124 & $-4.63 * * *$ \\
\hline CR & 0.0003314 & $2.84 * * *$ & 0.0003892 & $3 * * *$ & -0.0003456 & $-1.79^{*}$ & 0.000128 & 1.07 & -0.000694 & $-1.98 * * *$ \\
\hline SIZE & 0.0021007 & 1.18 & -0.0041115 & $-2.08 * * *$ & -0.0008403 & -0.29 & 0.0011137 & 0.61 & 0.0026685 & 0.5 \\
\hline ROE & 0.0206361 & 1.43 & 0.1807818 & $11.31 * * *$ & -0.5227606 & $-22 * * *$ & 0.1398968 & $9.53 * * *$ & -0.8409599 & $-19.47 * * *$ \\
\hline BOD & 0.0001121 & 0.11 & 0.0007109 & 0.61 & -0.004979 & $-2.87 * * *$ & 0.0026571 & $2.48 * * *$ & -0.0084911 & $-2.7 * * *$ \\
\hline MOIG & 0.0358383 & $33.1 * * *$ & 0.0015658 & 1.3 & -0.0128903 & $-7.2 * * *$ & 0.020194 & $18.27 * * *$ & -0.0210524 & $-6.47 * * *$ \\
\hline SAL & 0.5403437 & $2.68 * * *$ & -0.0676798 & -0.3 & -0.1694873 & -0.51 & 0.5088143 & $2.47 * * *$ & -0.4859849 & -0.8 \\
\hline AdjustR2 & 0.2415 & & 0.0466 & & 0.1838 & & 0.1356 & & 0.152 & \\
\hline F value & $174.75 * * *$ & & $27.65 * * *$ & & $123.89 * * *$ & & $86.61 * * *$ & & $98.85 * * *$ & \\
\hline $\begin{array}{l}\text { Sample } \\
\text { size }\end{array}$ & 3821 & & 3821 & & 3821 & & 3821 & & 3821 & \\
\hline
\end{tabular}

Note: $* * *, * *, *$ are significant at $1 \%, 5 \%$ and $10 \%$ levels respectively.

The results show that in private listed companies, accrued earnings management and real earnings management are significantly negatively correlated with internal control. In general, it can verify the relevant contents of hypothesis 1 and 2 in this paper. Moreover, by comparing the absolute values of regression coefficients of DNDA and DREM with IC, it is not difficult to find that improving the quality of internal control has a greater effect on reducing the true earnings management than on reducing the accrued earnings management.
In addition, we can get the results of related control variables: MOIG is significantly positively correlated with DNDA at $1 \%$ level and negatively correlated with DREM, which shows that companies with better growth and larger development space prefer to increase accounting earnings to attract investment funds; CR is negatively correlated with DREM at $1 \%$ level of significance, and positively correlated with DNDA, which means that companies with higher equity. Accountants choose earnings management as the main means of earnings management in highly centralized companies; ROE is negatively correlated with DREM at 
$1 \%$ level, which indicates that companies with poor profitability are more likely to have earnings management in real activities than those with high profitability; BOD and DREM are negatively correlated at $1 \%$ level, which indicates that directors with large scale are more likely to have earnings management in real activities. SAL is positively correlated with DNDA at $1 \%$ level. Executive compensation incentives are often linked to corporate performance. Managers are likely to manipulate corporate earnings to maximize their own value in order to earn personal benefits.

\section{Research conclusions}

For private listed companies, internal control is an important factor affecting earnings management, and internal control has a significant negative correlation with accrued earnings management and real earnings management. That is, having a good and rigorous internal control system can effectively reduce the degree of accrued earnings management and real earnings management. And compared with the real activity earnings management, the effect of internal control in reducing the degree of accrued earnings management is more obvious. There are many factors that affect the earnings management of private enterprises. The more concentrated the ownership, the lower the quality of earnings management in accounting choice, and the higher the quality of earnings management in real activities; the lower the return on net assets, the lower the quality of earnings in real activities; the larger the board of directors, the higher the quality of earnings management in corresponding companies; the more likely companies with high growth rate of operating income are to carry out earnings management in accounting choice; and the higher the level of managerial remuneration, the greater the management. Real earnings management is used by managers to manipulate the extent of profits. In order to obtain more wages and benefits, managers use earnings management to manipulate profits.

\section{References}

1. Doyle, J.,Ge, W., and McVay, S. Determinations of Weaknesses in Internal Control over Financial Reporting and the implications for Earnings Quality. 2005.[J]. Working Paper, University of Utah.

2. Chan, K.C.B. Farrell, and P. Lee. Earnings Management of firms Reporting Material Internal Control Deficiencies and Their Remediation on Accrual Quality, The Accounting Review, 2008, 83(1):217 250.

3. Ashbaugh-Skaife, Collins D and Kinney W and LaFound R, The Effect of SOX Internal Control Deficiencies and Their Remodiation on Accrual Quality, Accounting Review, 2008, 83(1).

4. Doyle, J. Weili Ge, Sarah McVay, Accrual Quality and Internal Control over Financial Reporting, The Accounting Review, 2007, 82(5):1141 1170.
5. Yu Zhongbo, Tian Gaoliang. Is the report of internal control evaluation really useful? Research on Finance and Accounting from the Perspective of Accounting Information Quality and Resource Allocation Efficiency, 2009 (9): 110-118. (In Chinese)

6. Zhang Guoqing. Internal Control and Earnings Quality - Based on the Empirical Evidence of Ashare Companies in $2007 \quad[\mathrm{~J}]$. Economic Management, 2008 (23): 112-119. (In Chinese)

7. Roychowdhury S, 2006, Earnings Management through Real Activities Manipulation. Journals of Accounting and Economic, 42(3):335 370.

8. Lu Jianqiao. Empirical Study on Earnings Management of Loss Listed Companies in China [J]. Accounting Research, 1999 (9): 25-35.(In Chinese) 